19. Sиввоta, O.W. (2005). Musical motor skills as a category of musicology. Candidate's thesis. Odessa / Odessa. state music. acad. named after A.V. Nezhdanova [in Ukrainian].

20. Tatarkevich, V. (1977). Ancient aesthetics. Moscow: Art [in Russian].

21. Fadeeva, I.E. (2004). Theory and cultural-historical phenomenology of the symbol. Doctor's thesis. SPb / Ros. state ped. University of Shimeni AI Herzen [in Russian].

22. Fortunatova, V.A. (1998). Man in the world of culture: textbook. allowance. N. Novgorod: NGPU. [in Russian].

УДК 78.452

DOI https://doi.org/10.31723/2524-0447-2020-30-2-23

Лариса Петрівна Мухіна

ORCID: 0000-0002-2381-7297

acniрант

Сумського державного педагогічного університету

імені А. С. Макаренка

Lorele_a@ukr.net

\title{
ВИКОНАВСЬКИЙ КОНЦЕПТ СОЛОМІЇ КРУШЕЛЬНИЦЬКОЇ В ІТАЛІЙСЬКІЙ ТА НІМЕЦЬКІЙ ОПЕРІ КІНЦЯ ХІХ - ПОЧАТКУ ХХ СТОЛІТЬ
}

Соломія Крушельницька є видатною примадонною світовою оперної сцени кін. XIX - поч. XX ст. Ï̈ творчість вплинула на розвиток українського оперного мистецтва, залишаючись невід'ємною частиною світової оперної культурної спадщини. Мета роботи - виявлення особливостей оперно-виконавської діяльності Соломії Крушельницької, яка є унікальною щодо своєї творчої майстерності. Методологія дослідження. Обгрунтовано аналітичне поняття «виконавський концепт», яке узагальнюе характерні риси виконавчої техніки та артистичного стилю співачки в контексті постановки конкретного художнього твору. Виконавський концепт включає характеристику творчого методу

(C) Мухіна Л. П., 2020 
оперної діви, зокрема ї̈ індивідуальне осмислення конкретного твору, власну роль у ньому (інтерпретація твору, прочитання образу), а також особливості виконавської техніки, які застосовуються для втілення сформованого образу (творчий метод). Наукова новизна статті полягає у розгляді творчості С Крушельницької в контексті аналізу ії творчого методу. Висновки. Зроблено висновок, що Соломія Крушельницька у своїй діяльності керувалася своєю концепцією художньої творчості, що включала аналіз твору та створення образу, заснованого на власній його творчій інтерпретації. С. Крушельницька послідовно поєднувала високі стандарти техніки вокалу з акторською майстерністю, для неї було характерним розумінням оперного мистеитва як мистецтва драматичного. Отже, виступи Соломії Крушельницької не зводилися до виконання оперних партій; їі ролі базувалися на виконавському концепті як інтегральному розумінні вокальних та художніх засобів, за допомогою яких втілювався цілісний образ. Вияви такого новаторського nідходу в період розквіту творчої діяльності співачки були характерною тенденцією розвитку оперного мистеитва, ї̈ діяльність можна розглядати як один із найяскравіших прикладів такого роду творчих експериментів.

Ключові слова: оперне мистецтво, виконавська діяльність Соломії Крушельницької, сценічні образи, італійські та німецькі композитори-реформатори, вокальна школа, академічний вокал.

Mukhina Larysa Petrivna, Postgraduate Student of the Sumy State Pedagogical University named after A. S. Makarenko

The performance concept of Solomiia Krushelnytska in the Italian and German operations of the end of the $19^{\text {th }}$ - early $20^{\text {th }}$ centuries

Solomiya Krushelnytska is a prominent diva world of the opera scene. $X I X$ - beginning. Twentieth century. Her work has influenced the development of Ukrainian opera art, while remaining an integral part of the world's operatic cultural heritage. Research objective. Therefore, it is of interest to analyze the features of the opera and performance of Solomiya Krushelnytska, which is unique in its creative skill. For the purpose of art analysis of the activity of Solomiya Krushelnytska, the analytical concept of the performing concept is substantiated, which summarizes the characteristic features of the performing technique and the artistic style of the singer in the context of the production of a particular work of art. The performing concept includes the characteristic of the creative method of the opera maiden, in particular its individual comprehension of a particular work, its own role in it (interpretation of the work, reading the image), as well as features of the performing technique that are used to translate the formed image (creative method). The scientific novelty of the article lies in the consideration of the work of S. Krushelnitskaya in the context of the analysis of her creative method. Conclusions. It is concluded that in his activity Solomiya Krushelnytska was guided by his concept of artistic creativity, which included analysis of the work and creation of an image based on his own creative interpretation. S. Krushelnytska consistently combined high standards of vocal technique with acting skills, for her was characterized 
by an understanding of opera as dramatic art. Thus, the performances of Solomiya Krushelnytska were not limited to the performance of opera parties; her roles were based on the performing concept as an integral understanding of vocal and artistic means through which a holistic image was embodied. The manifestations of such an innovative approach during the heyday of the singer's creative activity were a characteristic tendency of the development of opera art, her activity can be considered as one of the most striking examples of this kind of creative experiments.

Key words: opera art, Solomiya Krushelnytska's performing activity, stage performances, Italian and German reformers, vocal school, academic vocals.

Мухина Лариса Петровна, аспирант Сумского государственного педагогического университета имени А.С. Макаренко

Исполнительский концепт Соломии Rрушельницкой в итальянской и немецкой опере конца XIX - начала XX веков

Соломия Крушельницкая является выдающимся примадонной мировой оперной сиены кон. ХІХ - нач. ХХ в. Ее творчество повлияло на развитие украинского оперного искусства, в то же время оставаясь неотбемлемой частью мировой оперной культурного наследия. Цель работы - выявление особенностей оперно-исполнительской деятельности Соломии Крушельницкой, которая является уникальной по своей творческого мастерства. Итак, интерес представляет анализ особенностей оперно-исполнительской деятельности Соломии Крушельницкой. Методология исследования. С иелью искусствоведческого анализа деятельности Соломии Крушельницкой обоснованно аналитическое понятие «исполнительный концепт», которое обобщает характерные черты исполнительской техники и артистического стиля певицы в контексте постановки конкретного художественного произведения. Исполнительный кониепт включает характеристику творческого метода оперной дивы, в частности ее индивидуальное осмысление конкретного произведения, собственную роль в нем (интерпретация произведения, прочитанные образа), а также особенности исполнительской техники, которые применяются для воплощения сформированного образа (творческий метод). Научная новизна статьи заключается в рассмотрении творчества С. Крушельницкой в контексте анализа ее творческого метода. Выводы. Сделан вывод, что Соломия Крушельницкая в своей деятельности руководствовалась своей концепиией художественного творчества, включала анализ произведения и создание образа, основанного на собственной его творческой интерпретации. С. Крушельницкая последовательно сочетала высокие стандарты техники вокала с актерским мастерством, для нее было характерно пониманием оперного искусства как искусства драматического. Итак, выступления Соломии Крушельницкой не сводились к выполнению оперных партий; ее роли базировались на исполнительском концепте как интегральном понимании вокальных и художественных средств, с помощью которых воплощался целостный образ. Проявления такого новаторского подхода в период расцвета творческой деятельности певицы были характерной 
тенденцией развития оперного искусства, ее деятельность можнн рассматривать как один из самых ярких примеров такого рода творческих экспериментов.

Ключевые слова: оперное искусство, исполнительская деятельность Соломии Крушельницкой, сценические образы, итальянские и немецкие композиторы-реформаторы, вокальная школа, академический вокал.

Актуальність теми дослідження. Розвиток світової музичної культури завжди пов'язаний з видатними постатями митців, творчість яких доленосно впливала на потужні зрушення у мистецтві. Зокрема, наприкінці XIX - на початку XX століть бурхливий розквіт опери був пов'язаний із новаторськими експериментами реформаторів оперного мистецтва Р. Вагнера, Дж. Верді, Дж. Пуччіні, Р. Штрауса, які урізноманітнили його та створили умови для розквіту цілої низки виконавських талантів кін. XIX - поч. XX ст. Успіх опери визначається взаємодією твору композитора та його представленням на сцені. Цей факт зумовлює унікальність оперних постановок та їхній особливий вплив на глядача. Вияв творчої геніальності композитора та природної обдарованості виконавця перебувають у синергічній взаємодії, дослідження якої, як правило, і є об’єктом аналізу театральної критики.

Постать Соломії Крушельницької належить до числа видатних виконавців аналізованого періоду. Вона відзначалася самовідданістю класичному співу та надзвичайною природною обдарованістю. Близько 70 оперних арій, неосяжний репертуар камерних творів, романсів, пісень народів світу, блискуче виконаних мовою оригіналу - це справжній мистецький подвиг, на який Крушельницька поклала все своє творче життя.

Як і щодо інших геніїв оперної сцени, можна говорити про феномен Соломії Крушельницької, вартий аналізу своїх унікальних особливостей, якими обумовлювалося сприйняття творчості співачки сучасниками.

Творчості С. Крушельницької було присвячено значну кількість публікацій, багато з яких з'явилися ще в час їі творчої кар'єри та складали відгуки та рецензії критиків і музикознавців. Пізніше були опубліковані узагальнювальні праці О. Бандрівської, І. Деркача, М. Головащенка. Фундаментальне значення для дослідження творчості С. Крушельницької мало двотомне видання під редакцією М. Головащенка корпусу спо- 
гадів, листів і рецензій про співачку, у яких знайшли відображення аспекти життя та творчості виконавиці. Творчу діяльність, особливості стильової та індивідуальної виконавської інтерпретації С. Крушельницькою оперних партій вивчали у своїх наукових розвідках В. Врублевська, Н. Бабинець, Д. Білавич, М. Головащенко, В. Горинь, Б. Гнидь, С. Павлишин, П. Медведик, О. Михайличенко. Особливе значення має інформація про унікальні риси виконавської творчості Соломії Амвросіївни, що міститься в критиці Р. Кортопассі, Дж. Дюваля, Г. Маротті, рецензіях С. Алерамо, Ф. Главачека. Серед новіших праць слід відзначити серію досліджень I. Комаревич, узагальнених у іiї дисертації, присвяченій аналізу психологічних та соціоісторичних компонентів творчості співачки. I. Комаревич робить спробу застосувати до аналізу сучасні психологічні концепції особистості. Втім, незважаючи на досить численну бібліографію творчості співачки, досі відсутня ii академічна біографія, а сама діяльність С. Крушельницької як творчий феномен здебільшого позбавлена аналітичної глибини й потребує поглибленого розгляду [7].

Метою статті $\epsilon$ аналіз виконавської діяльності С. Крушельницької в контексті розвитку світового оперного мистецтва кінця XIX - початку XX століть, яке пов'язане із оперними реформами провідних композиторів італійської та німецької шкіл. Це дозволяє визначити складники виконавської та акторської майстерності С. Крушельницької та обгрунтувати їх у рамках поняття виконавського концепту у творчості співачки.

Предметом статті є творчість Соломії Крушельницької в італійській та німецькій опері кінця XIX - початку XX ст.

Об'єктом статті є виконавські концепти у творчості видатної української виконавиці.

Наукова новизна статті полягає в розгляді творчості С. Крушельницької в контексті аналізу іiі творчого методу.

Методи дослідження. У статті використано методологію історико-культурного та мистецтвознавчого дослідження. Творчість співачки розглянуто на основі широкого кола історичних джерел, які включають мемуари та епістолярну спадщину, матеріали періодичної преси. Із метою мистецтвознавчого аналізу діяльності С. Крушельницької обгрунтовано аналітичне поняття «виконавський концепт», яке узагальнює характерні риси виконавчої техніки та артистичного стилю 
співачки в контексті постановки конкретного художнього твору. Виконавський концепт мислиться як «проникнення та розкодовування авторського задуму та побудови... інтерпретації» ролі [2, с. 25]. Виконавський концепт включає характеристику творчого методу виконавиці, зокрема іiі індивідуальне осмислення конкретного твору, власну роль у ньому (інтерпретація твору, прочитання образу), а також особливості виконавської техніки, які застосовуються для втілення сформованого образу (творчий метод).

Виклад основного матеріалу. Співацька кар'єра Соломії Амвросіївни почалася після закінчення консерваторії Галицького товариства у Львівській опері (1893), де вона успішно виконувала партії Леонори в опері «Фаворитка» Г. Доніцетті та Сантуцци в опері «Сільська честь» П. Масканьї. Незважаючи на досягнутий успіх, за порадою італійської співачки Джемми Беллінчоні Крушельницька восени 1893 року їде до Італії вдосконалювати вокальну майстерність у відомого професора Фаусти Креспі. Важливо відзначити, що разом із навчанням вокалу С. Крушельницька вивчала акторську гру у професора Конті [8, с. 68].

Уже за рік від початку навчання в Мілані С. Крушельницька успішно виконує провідні партії на італійських сценах. Однак 1894 року вона була вимушена повернутися до львівського театру, де починала свою кар'єру й де цього разу вона співала партії головних героїнь у «Фаусті» Ш. Гуно, «Трубадурі» й «Бал-маскараді» Дж. Верді, «Гальці» С. Монюшка, «Дочці кардинала» Ф. Галеві, «Африканці» й «Гугенотах» Дж. Мейєрбера та ін. Однак нове трактування образів героїнь та інакша манера співу суперечили еталонам, до яких призвичаїлися львівські професори й публіка, і спровокували негативне ставлення до співачки та несприйняття іiі вокального i сценічного втілення образів. Негативна, сповнена кулуарних інтриг атмосфера театру змушувала Соломію Крушельницьку постійно чекати на розірвання контракту.

\section{Вердіївські партії}

Ситуацію змінила робота Крушельницької в «Аїді» Дж. Верді, якою вона захопилась ще під час навчання в Мілані. Вочевидь, що героїня оперного творіння Дж. Верді була дуже близькою до натури Крушельницької, що вона відзначає власноруч $[10 ; 11]$. Відтоді роль єгипетської рабині стає провідною в репертуарі Крушельницької. Вона співатиме 
цю партію на головних оперних сценах світу в сузір'ї найвидатніших співаків епохи - Е. Карузо (Радамес), М. Баттістіні (Амонасро), В. Арімонді (Рамфіс).

Участь С. Крушельницької в операх «Сила долі», «Трубадур», «Бал-маскарад» принесла їм надзвичайний успіх на сценах Парижа, Неаполя, Палермо, Туріна, Мадрида, Барселони, Буенос-Айреса, Ріо-де-Жанейро, Рима, Болоньї, Сантьяго, Варшави, Санкт-Петербурга, Нью-Йорка, Оттави. Для «вердівського» співака виконання - це не тільки «forte» та найтонше «pianissimo», а й володіння «messadivoce» (інше, ніж «mezzovoce») та «chiaroscuro» (світлотіні). Хоча композитор гарно знався на співацьких голосах, однак сучасники визнавали його «Аттілою голосів», тобто їхнім руйнівником, особливо після прем'єр «Набукко», «Ломбардців», «Ернані» та інших ранніх опер (зокрема, майбутня дружина Верді, співачка Джузеппіна Стреппоні, незабаром після прем'єри «Набукко» назавжди втратила голос). Використання крайніх звуків співацького діапазону, нівелювання граней між аріозністю та речитативом, широка палітра динамічних відтінків при надзвичайній психологічній експресії - це вкрай непрості завдання для вокалістів. Цікаво, що у 1863 році Віденська опера після численних репетицій взагалі відмовилася від постановки «Трубадура», визнавши його неможливим для виконання.

Аїда стала творчим успіхом для Соломії Крушельницької. У 1870 - 1880-х роках традиції виконання партії головної героїні опери Дж. Верді на європейських оперних сценах мали певний усталений стереотип. За словами С. Крушельницької, які передає Д. Банфі-Малагуцці, опери Дж. Верді вона розцінювала як порівняно прості й позбавлені драматичної складності, що, на іiі думку, заважало виконавицям виявити власну творчу індивідуальність [1, с. 236]. Як наслідок, акцент у виконанні робився на демонстрацію можливостей голосу артистки, технічної досконалості у виконанні вокальних партій. Аналіз відгуків критики і спогадів сучасників С. Крушельницької вказує на те, що вона послідовно намагалася поєднувати доскональне технічне виконання із переконливою акторською грою, заснованою на власному, глибокому розумінні втілюваних образів. Це виявилося вже на початку іiі творчої кар'єри. Вона «надзвичайно правдиво входить в образ», «керується якимось естетичним інстинк- 
том» [13]. Під цим «естетичним інстинктом» малась на увазі, як вказувала сестра співачки, Олена Крушельницька-Охримович, праця із осмислення та трактування ролі [8, с. 61].

Судячи з відгуків критики, у виконанні Аїди С. Крушельницька досягала вражаючого ефекту на публіку. За враженням Дж. Мональді, створюваний С. Крушельницькою образ Аїди був настільки далеким від тогочасного стереотипного уявлення про цю роль, що здавався «майже карикатурним» [14, с. 128].

Ще до праці над образами Верді ця риса виконання С. Крушельницької була відзначена за іiі ролями в операх С. Монюшка «Галька» і «Графиня». Вокальними засобами вона виражала «настрій, відчуття, думку, акцент слова». Не допускаючи «надмірного драматизму», С. Крушельницька в «Гальці» досягала «життєвої правди» образу, піднімаючи значення опери і як вокального, і як драматичного твору [15]. У «нечувано важкій» із технічного боку партії С. Крушельницька досягала сильного емоційно-психологічного ефекту, «підпорядковуючи звуки словам» та створюючи відповідно до характерного для С. Монюшка стилю «музиканта-поета» засновану на втіленні почуття декламацію [3].

Подібний ефект досягався свідомо. За спогадами учнів С. Крушельницької у Львівській державній консерваторії, вона наполягала на технічній «природності» співу, який би грунтувався на комфортному ритмі дихання виконавця та на художній виразності співу, його осмисленості, зумовлених детальним розумінням образу [4, с. 336]. Звертають на себе увагу візуальні акценти у відгуках, які надавали щодо ролей С. Крушельницької різні спостерігачі-очевидці. Частими $є$ їхні поради «дивитися» на виконання [9], «дивитися так само, як і слухати»[5; 6].

\section{Вагнерівські ролі}

C. Крушельницька отримала визнання і як виконавиця ролей у творах іншого оперного композитора-реформатора P. Вагнера, відзначившись і як «вагнерівська примадонна ХХ століття». Музику Р. Вагнера С. Крушельницька визначала як суттєвий етап у розвиткові опери як драматичного мистецтва. Створення жіночих образів Вагнера із притаманною їм героїчною естетикою було для неї «великою, але й не легкою радістю» [1, с. 236]. Виконання їх для недостатньо досвідченої співачки С. Крушельницька розцінювала як ризиковане [10]. Протягом чотирьох місяців вона вивчала творчість 
композитора у відомого віденського професора Йозефа Генсбахера. Вимогливість до себе й постійні репетиції дозволяли Крушельницькій впоратися навіть із теситурою колоратурного сопрано. Як наслідок, вона однаково вільно володіла і італійською, і німецькою манерами співу, що на той час було не частим явищем [7, с. 40]. Врешті, метод актриси дозволив досягнути успіху й у творах Вагнера: «Вона наче спеціально створена для виконання опер Вагнера», - відзначав музичний критик Д. Дюваль [5; 6, с. 43]. У «Тристані і Ізольді» образ С. Крушельницької названо «ідеальною Ізольдою», iii спів відзначений такою характеристикою, як «всевладна експресивність» [16].

\section{Пуччіні}

Успішними для С. Крушельницької вважаються ролі, втілені в операх Дж. Пуччіні, із яким вона була близько знайомою особисто та тісно співпрацювала. Найбільш відомим із цієї співпраці є успішне відтворення опери «Мадам Баттерфляй». Перша постанова, яка відбулася 17 лютого 1904 р. у «Ла Скала» із Р. Сторкіо в ролі Чіо-Сіо-сан, провалилася. Це змусило Дж. Пуччіні відкоригувати твір і погодитися на другу постанову із С. Крушельницькою в головній ролі. 28 травня 1904 р. у Гранд Театрі у Брешії відбулася друга постанова, яка мала повний успіх. Постанова була цікавою в ряді аспектів. Упродовж тривалого часу С. Крушельницька вживалася в образ. Дж. Монаді вказує, що С. Крушельницька була вільною у своїх творчих пошуках і послідовно втілювала власний погляд навіть тоді, коли він вочевидь не імпонував публіці [14, с. 127].

\section{Штраус - “Саломе”, “Електра”}

Етапними для творчості співачки були іiі ролі в операх Ріхарда Штрауса. Творчість Р. Штрауса суперечливо сприймалася в колах музикантів, публіки та критики: від надзвичайного захоплення до іронізування та цілковитого відторгнення. Опери «Саломе» та «Електра» написані на сюжети творів Оскара Уайльда та Гуго фон Гофмансталя - яскравих представників європейського декадансу. Їм притаманна незвичність гармоній та надзвичайна складність вокальних партій, яка, до того ж, відрізняється загостреною емоційністю та особливою гіпертрофованою образністю. Сама С. Крушельницька відзначала особливості творчого стилю Р. Штрауса [1, с. 238]. Запрошена виконати роль Саломе, С. Крушель- 
ницька, як завжди, дуже серйозно поставилась до завдання. Виступ співачки мав успіх [12, с. 4].

Звертаючись до виконання найскладніших оперних партій, які на рівні широкого діапазону вокально-технічних можливостей голосу вимагають від виконавця цілком відповідного широкого діапазону відтворення почуттів: від трагічного зойку до замріяного ліризму, від кохання до жорстокої ненависті, від вольового опору до тихої покори, С. Крушельницька виступає як «універсальна» творча постать, яка незвичайним драматичним талантом, унікальним та витонченим художнім смаком створила неповторні оригінальні сценічні образи в операх провідних композиторів-реформаторів Дж. Верді, Дж. Пуччіні, Р. Вагнера, Р. Штрауса.

Висновки. С. Крушельницька у своїй діяльності керувалася власною концепцією художньої творчості, яка включала аналіз твору та створення образу, заснованого на власній його творчій інтерпретаціі. Співачка послідовно поєднувала високі стандарти техніки вокалу з акторською майстерністю, для неї було характерним розуміння оперного мистецтва як мистецтва драматичного. Отже, виступи С. Крушельницької не зводилися до виконання оперних партій; іiі ролі базувалися на виконавському концепті як інтегральному в розумінні вокальних та художніх засобів, за допомогою яких втілювався цілісний образ. Вияви такого новаторського підходу в період розквіту творчої діяльності С. Крушельницької були характерною тенденцією розвитку оперного мистецтва, іiі діяльність можна розглядати як один із найяскравіших прикладів такого роду творчих експериментів. Найбільший успіх мав виконавський концепт С. Крушельницької, втілений в «Аїді», ролях опер вагнерівського циклу («Валькірія», «Тангейзер», «Тристан і Ізольда»), творах С. Монюшка («Галька», «Графиня»), Р. Штрауса («Саломе», «Електра»). Особливе значення має роль Чіо-Чіо-сан у прем'єрі другої версії опери Дж. Пуччіні «Мадам Батерфляй», виконавський концепт якої та його роль в успіху цієї опери потребує подальшого дослідження. Проте навіть представлений огляд дає підстави стверджувати, що, маючи досконалу вокальну школу, незрівнянної краси та сили голос, незвичайний драматичний талант та витончений художній смак, видатна українська співачка створила повнокровні оригінальні образи оперних героїнь. 


\section{СПИСОК ЛІТЕРАТУРИ}

1. Банфі-Малагуцці Д. Бесіда із Соломією Крушельницькою. Соломія Крушельницька. Спогади. Матеріали. Листування / упоряд. вступ.ст. та приміт. М.І. Головащенко: у 2 ч. Київ : Музична Україна, 1978. Ч. 1. С. 234-242.

2. Власенко Е.А. Перспективні шляхи формування комунікативних якостей майбутнього вчителя музичного мистецтва. Теоретические и практические научные инновации. 2014. Т. 3. С. 25-27.

3. Kurier Warszawsski, № 345, 346, 1900 р. Соломія Крушельницька. Спогади. Матеріали. Листування: у 2 ч. / упоряд. вступ.ст. та приміт. М.I. Головащенко. Київ : Музична Україна, 1979. Ч. 2. С. 41-45.

4. Гринишин М. У вінок слави. Соломія Крушельницька. Спогади. Матеріали. Листування / упоряд. вступ.ст. та приміт. М.І. Головащенко: у 2 ч. Київ: Музична Україна, 1978. Ч. 1. С. 335-341.

5. Дюваль Д. Артисти, яких ми ще не чули. Соломія Крушельницька. Спогади. Матеріали. Листування: у 2 ч. / упоряд. вступ.ст. та приміт. упоряд. вступ.ст. та приміт. М.І. Головащенко. Київ : Музична Україна, 1978. Ч. 1. С. 195-198.

6. Дюваль Д. Велика серед великих: Італійці про Соломію Крушельницьку: Спогади, газетно-журнальні публ. / Клуб укр. інтелігенції ім. Б. Лепкого; упоряд. У. Скальська. Івано-Франківськ : Грань, 2003. 75 с.

7. Комаревич І.Л. Психологічні та соціоісторичні компоненти музично-сценічної життєтворчості Соломії Крушельницької : автореф. дис. ... канд. Мистецтвознавства : 17.00.03. ; Львів. нац. муз. акад. ім. М.В. Лисенка. Львів, 2016. 16 с.

8. Крушельницька-Охримович О. Все, що залишилося в пам'яті про Соломію. Соломія Крушельницька. Спогади. Матеріали. Листування: у 2 ч. / упоряд. вступ. ст. та приміт. М.І. Головащенко. Київ : Музична Україна. 1978 Вип. 1. С. 46-69.

9. Лаурі-Вольпі Д. Велика артистка. Соломія Крушельницька. Спогади. Матеріали. Листування: у 2 ч. / упоряд. вступ.ст. та приміт. М.І. Головащенко. Київ : Музична Україна, 1978. Ч. 1. С. 180-181.

10. Лист С. Крушельницької до М. Павлика від 4 квітня 1894 року. Соломія Крушельницька. Спогади. Матеріали. Листування: у 2 ч. / упоряд. вступ.ст. та приміт. М.І. Головащенко. Київ : Музична Україна, 1979. Ч. 2. С. 218.

11. Лист С. Крушельницької до М. Павлика від 10 березня 1894 року. Соломія Крушельницька. Спогади. Матеріали. Листування: у 2 ч. / упоряд. вступ.ст. та приміт. М.І. Головащенко. Київ : Музична Україна. 1979, Ч. 2. С. 187.

12. Маротті Г. Сенсація і тріумф / підгот. М. Головащенко. Вільне життя. 1973, 19 вересня.

13. Мила несподіванка. Соломія Крушельницька. Спогади. Матеріали. Листування: у 2 ч. / упоряд. вступ.ст. та приміт. М.I. Головащенко. Київ: Музична Україна, 1979 Ч. 2. С. 16-17. 
14. Мональді Д. Славетна співачка. Соломія Крушельницька. Спогади. Матеріали. Листування: у 2 ч. / упоряд. вступ.ст. та приміт. М.І. Головащенко. Київ : Музична Україна, 1978. Ч. 1. С. 127-128.

15. Сигетинський А. Соломія Крушельницька. Спогади. Матеріали. Листування: у 2 ч. / упоряд. вступ.ст. та приміт. М.І. Головащенко. Київ : Музична Україна, 1979. Ч. 2. С. 26-29.

16. Тристан та Ізольда. Соломія Крушельницька. Спогади. Матеріали. Листування: у 2 ч. Київ : Музична Україна, 1979. Ч. 2. С. 121-122.

\section{REFERENCES}

1. Banfy-Malaguzzi, D. (1978). Interview with Solomiia Krushelnytska. ed. by Mykhailo Golovashchenko. Solomiia Krushelnytska. Memoirs. Materials. Correspondence: in 2 volumes. Kyiv: Muzychna Ukraina, 1, 234-242 [in Ukrainian].

2. Vlasenko, E. A. (2014). Prospective Ways of Forming the Communicative Qualities of the Future Teacher of Music Art. Theoretical and Practical Scientific Innovations. 3, 25-27 [in Ukrainian].

3. Kurier Warszawsski Newspaper, No. 345, 346, 1900 (1979). ed. by Mykhailo Golovashchenko. Solomiia Krushelnytska. Memoirs. Materials. Correspondence: in 2 volumes Kyiv, Muzychna Ukraina, 2, 41-45 [in Ukrainian].

4. Hrynyshyn, M. (1978). In the Wreath of Glory. ed. by Mykhailo Golovashchenko. Solomiia Krushelnytska. Memoirs. Materials. Correspondence: in 2 volumes. Kyiv, Muzychna Ukraina, 1, 335-341 [in Ukrainian].

5. Duvall, D. (1978). Artists we Haven't Heard Before. ed. by Mykhailo Golovashchenko. Solomiia Krushelnytska. Memoirs. Materials. Correspondence: in 2 volume. Kyiv, Muzychna Ukraina, 1, 195-198 [in Ukrainian].

6. Duvall, D. (2003). Great among the Great. Italians about Solomiia Krushelnytska: Memoirs, Newspaper and Magazine Publications. Ed. by U. Skalska. Hran, Ivano-Frankivsk [in Ukrainian].

7. Komarevych, I. L. (2016). Psychological and Sociohistorical Components of Solomiia Krushelnytska's Musical and Performing Life: Thesis for PhD in Art Studies: 17.00.03. Lviv National Music Academy named after Mykola Lysenko, Lviv [in Ukrainian].

8. Krushelnytska-Okhrymovych, O. (1978). All that the Memory Retains about Solomiia. ed. by Mykhailo Golovashchenko. Solomiia Krushelnytska. Memoirs. Materials. Correspondence: in 2 volumesKyiv, Muzychna Ukraina, 1, 46-69 [in Ukrainian].

9. Laurie-Volpi, D. (1978). Great Artist. ed. by Mykhailo Golovashchenko. Solomiia Krushelnytska. Memoirs. Materials. Correspondence: in 2 volumes. Kyiv, Muzychna Ukraina, 1, 180-181 [in Ukrainian].

10. Letter from S. Krushelnytska to M. Pavlyk dated April 4, 1894 (1979). Ed. by Mykhailo Golovashchenko. Solomiia Krushelnytska. 
Memoirs. Materials. Correspondence: in 2 volumes (Vol. 2: Materials. Correspondence, Pp. 218). Kyiv, Muzychna Ukraina [in Ukrainian].

11. Letter from S. Krushelnytska to M. Pavlyk dated March 10, 1894 (1979). ed. by Mykhailo Golovashchenko. Solomiia Krushelnytska. Memoirs. Materials. Correspondence: in 2 volumes. Kyiv, Muzychna Ukraina, 2, 187 [in Ukrainian].

12. Marotti, G. (1973, September 19). Sensation and Triumph / prepared by M. Golovashchenko. Vilne Zhyttia [in Ukrainian].

13. Cute Surprise (Gazeta Lwowska. August 23, 1895). (1979). Ed. by Mykhailo Golovashchenko. Solomiia Krushelnytska. Memoirs. Materials. Correspondence: in 2 volumes. Kyiv, Muzychna Ukraina, 2, 16-17 [in Ukrainian].

14. Monaldy, D. (1978). The Glorious Singer. ed. by Mykhailo Golovashchenko. Solomiia Krushelnytska. Memoirs. Materials. Correspondence: in 2 volumes. Kyiv, Muzychna Ukraina, 1, 127-128 [in Ukrainian].

15. Sighetinsky, A. (1979). Slowo, March 15, 1899. ed. by Mykhailo Golovashchenko. Solomiia Krushelnytska. Memoirs. Materials. Correspondence: in 2 volumes. Kyiv, Muzychna Ukraina, 2, 26-29.

16. Tristan and Isolde, Deutsche La Pfatta Zeitung, July 28, 1906 (1979). Ed. by Mykhailo Golovashchenko. Solomiia Krushelnytska. Memoirs. Materials. Correspondence: in 2 volumes. Kyiv, Muzychna Ukraina, 2, 121-122 [in Ukrainian]. 